Volume \& Issues Obtainable at The Women University Multan
International Journal of Linguistics and Culture
ISSN (Print): 2707-6873, ISSN (Online): 2788-8347
Volume 2, No.1, June 2021
Journal homepage: http://ijlc.wum.edu.pk/index.php/ojs

\title{
Portrayal of Islamic Ideology: Modality analysis of PTB English language textbooks
}

\author{
Rashid Mahmood \\ Visiting Lecturer of English, University of Okara, Pakistan \\ Email: rashidma91@gmail.com \\ Dr. Adnan Tahir \\ (Corresponding author) \\ Associate Professor of English, Emerson University, Multan \\ Email: adnan.tahir@gecmultan.edu.pk
}

\author{
Afzal ul Haque \\ MPhil English Scholar \\ RIPHAH International University, Faisalabad \\ Email: afzaal2015ok@gmail.com
}

\begin{abstract}
This paper investigates English language textbooks from the point of view of cultural development in pedagogical text. The focus of present study was to analyze contrasting and shared perceptions of congenital Islamic culture in pedagogical text broadly written in English language textbooks formed by Punjab Textbook Board (PTB) at Elementary level i.e. $6^{\text {th }}$, $7^{\text {th }}$, and $8^{\text {th }}$ grade classes. Appropriate implications of linguistic modality make possible to build ideological viewpoint related to cultural development in political, social, institutional and media discourse, so, using critical approach with the combination of CDA framework by Fairclough and SFG by Halliday. This study examines the said institutional discourse from different perspectives to clue that how fundamental Islamic philosophy is sharply described under different circumstances. The study is also an exposure of authors' viewpoint related to portrayal of Islamic culture and needs of cultural sensitivity in such a text related to young learners' education. In this way, this paper reveals the straightforward instances related to implicit portrayal of Islamic ideology with the help of numerous modality indicators. It has been observed that language textbooks are not only an authentic source of language learning but also a reliable system of cultural development. Findings of this paper expose that writers, policy makers and publishers of PTB want to portray Islamic ideology intentionally within the pedagogical text of English language textbooks at elementary level, so, the findings of this paper would be helpful for learners, educationists, course designers, institutions and language teachers.
\end{abstract}

Keywords: Modality, Textbooks, Ideology, Discourse 


\section{INTRODUCTION}

Every established country constructs some specific rules, norms, traditions, beliefs, integrities related to their specific culture to fulfill aesthetic sense among its inhabitants. These targets are achieved through political, religious, institutional and societal discourses whereas, institutional contribution relating to cultural development have off course prodigious impact. While analyzing any political, media, social or pedagogical text, different objectives, e.g., racism, gender perspectives, aesthetic values, religious values, regional traditions and nationalism are considered. Since education is a primary source of cultural development and it cannot exist without books especially without language books; so, language books could be treated as core element of society building as well as cultural development (Asghar, 2013). Through appropriate teaching and motivation of language learners, it would be made possible to establish cultural ideologies using any target language (Pennycook, 2010).

Generally, it is believed that language learning has close relations with economic and cultural development, so, language affects cultural improvement implicitly or explicitly and if the learners are provided appropriate cultural pedagogical text they would be able to express their beliefs in target language (Bahrami, 2015). As for Pakistani political, social, economic, and cultural values are concerned, the most valuable, prominent and ethical ideology of Pakistani culture is Islamic way of life and Islamic traditions are intentionally followed all over Pakistan by the youth and old generation of the country (Mahmood, Asghar, \& Hussain, 2012).

In this paper, elementary level $\left(6^{\text {th }}, 7^{\text {th }}, 8^{\text {th }}\right)$ English language textbooks produced by PTB have been analyzed to discover specific cultural ideologies related to Islamic values which have been constructed through significant use of linguistic modality. As a global language, English has economic, social, ideological and cultural impact on each and every country in which it is being taught as $2^{\text {nd }}$ language and in non-English countries it is treated as tool of development and success (van Dijk, 1993). Ideas, faiths, beliefs, norms, and ideologies relating to national culture embedded in apagogical text especially in $2^{\text {nd }}$ language textbooks, sometimes do not paint accurate cultural face of the society while sometimes these texts are not taught intentionally but have proper cultural components. In Pakistani pedagogical context, cultural development would be possible through developing motivational pedagogical text as well as teacher's training. For this purpose, a system 
can be developed for training of $2^{\text {nd }}$ language teachers to raise their consciousness relating to ideological expectations fixed in English language textbooks.

\section{Background of the study}

This paper is an exploration of cultural representations related to Islamic ideology within English language textbooks at elementary level presented by Punjab Textbook Board (PTB) Pakistan. The data for this research was collected from all three English textbooks of $6^{\text {th }}, 7^{\text {th }}$ and $8^{\text {th }}$ grades which are being practiced in public as well as private sector institutions all over the Province of Punjab, Pakistan. The criteria which was exposed in present research through appropriate applications of modality analytical tools were proposed by Fairclough (1989) in CDA and Halliday (1994) in SFG. Both models have sufficient modality analytical implications to unveil concealed ideologies from any type of text related to print, social and electronic media discourse, pedagogical discourse or any other discourse existed in society. In this way CDA could be a cornerstone because it was considered as first theoretical framework which had deep insight to any type of discourse meanwhile it could be more beneficial with integration of FSG by Halliday (1973) as he declared that “... language is as it is because of its function in social structure, and the organization of the behavioral meanings should give some insights into its social foundations" (Halliday, 1973, p. 65). So, in this way, the present study critically explored the criteria in which Islamic ideology was embedded in PTB English language textbooks at elementary level through significant applications of modal verbs.

Islamic ideology is concerned with basic factors related to emergence of Pakistan, i.e., 'language, religion and social traditions' all are important, no doubt, but Islam has hegemonic values in this regard and because it is a fundamental way of life for every Muslim it is treated as a basic social framework in Pakistan (Yaqoob \& Zubair, 2012). There are different regional and dialectical traditions in different domains of the country, but Islam is accepted as a religion and as a common symbolic cultural framework all over the Pakistan (Mansoor, 2004).

Culture provides pavement to the society and different social institutions have to support social class to maintain harmony of peace, love and unity within that particular society. In fact, people of a particular society take cultural grounds and practical situations related to region, religion and traditions by which they create a situation for learning particular standards of their society through teaching of language (McKay, 2003). The study of Pakistani history provides information about a 
mixture of cultural trends which have been developed due to associations of numerous communities who came from different parts of the world and used to live in sub-continent. They introduced different cultures like Islamic way of life, regional traditions and patriotism (Yaqoob \& Zubair, 2012). Pakistan, as an Islamic state has its own socio-cultural, political and economic values which could be observed through lifestyle of its young generation as well as adults because they follow all cultural values especially patriotic and Islamic values (Mahmood, Asghar, \& Hussain, 2012). In Pakistani pedagogical context, all over the Pakistan, books are considered as an authentic and authoritative tool for development of Pakistani cultural values especially Islamic values among young learners (Asghar \& Sulaimani, 2017).

Since discourse or text has great concern with development of culture; language textbooks are treated as basic cultural development tool (Qadeer, Tahir, Chishti, \& Ali, 2020). As a lingua franca all over the world, English has central value as a language for maintenance of culture in all countries of the world. As the culture and language are interrelated and affect each other, it is significant to investigate language books to unveil implicit and hidden agenda which constructs specific cultural ideology. As a foreign language it could be treated that English might portray foreign culture, so, this research investigates the notion whether these books portray Pakistani culture appropriately or text of these books portray foreign culture. The main agenda of this paper is to investigate representations of Islamic ideology through significant usage of linguistic modality. The study has investigated how elementary level English textbooks portray Islamic cultural values in Pakistan and how linguistic modality contribute to construct cultural values within a pedagogical text.

\section{LITERATURE REVIEW}

Specified standards related to culture shape society through social, political, public and institutional discourse. So, some cultural standards, norms, beliefs, traditions and rules differentiate societies all over the world and these standards would be observed through specific cultural understandings of the individuals of any particular society. Significant discourse indicators which are being used by any particular society are exposed and analyzed through CDA analytical tools appropriately because $\mathrm{CDA}$ is an influential and reasonable approach (Alrefaee, Abdul-Ghafour, Alazzany \&Alrefaee, 2019).

\section{Cultural development and language textbooks}


This is a day of tendency regarding elaboration societal, cultural, economic and political representations within English language textbooks (McConachy \& Hata, 2013). Cultural ideologies are being exposed by researchers and scholars through unique and distinctive linguistic features from language textbooks (Peled-Elhanan, 2012). If English language is learnt in appropriate context, it would introduce its target culture among young learners (Byram et al. 1991). Asghar (2013) argues that it depends on student's cultural awareness so that they would be motived easily while teaching English language. If students are motivated to express their own cultural values through English language, they will transmit their relational and religious culture accordingly (Pennycook, 2010; Bahrami, 2015). Literature books or language books, teachers and institutions have no doubt, unique impact on societal and cultural development (Samovar \& Porter, 2004).

In Pakistan, PTB textbooks can be treated a real reflection of Pakistani culture because there are various text indicators exist in the text of secondary level PTB English textbooks which portray a real picture of Islamic culture of Pakistan (Tahir \& Iqbal, 2012). Patriotic and Islamic ideologies are being portrayed more appropriately and precisely in PTB English language textbooks than all other English language textbook series practiced in province of Punjab (Yaqoob \& Zubair, 2012). Though PTB English language textbooks is presenting Islamic culture in a reasonable and significant way yet some lexical features portray foreign culture implicitly (Mahmood, Rasheed, Obaid \& Shakir, 2014).

\section{Cultural establishment in society}

Essentialist, politician, religious preachers and upper-class entities instruct young generation as well as adults about typical values, heritage and standards of culture traditionally represented in literature and do not allow them to adopt revolutionary changes related to culture (Morris, 2014). Cultural impact is neither removed nor replaced easily from any society because cultural values, norms, habits and traditions make social entities united as a single nation, but it could be changed or replaced slowly (Schwartz, 2006). Cultural behavioristic values and way of life make possible for researchers to expose and criticize credibility of any particular cultural behavior (Chen \& French, 2008). Developmental values and socio-cultural values shape culture to be established in a social setting, while on analytical side it allows researchers to maintain critical insight for understandings about that particular culture (Trommsdorff, 2000). Another aspect of society is family system which 
expresses specific norms, traditions, beliefs and behaviors adopted from elders or parents, family members act as act their predecessors (Trommsdorff, 2000).

\section{Social and cultural development of Pakistan}

According to cultural and historical development of culture in Pakistan, there was a blend of many cultures related to different countries from surroundings of Pakistan. There were Indian, Afghani, Asian, Persian, Sindhi and Arabic cultures before emergence of Pakistan and these nations had ruled for a long time in this area, the Sub-continent. They had different traditions according to their geographical and ethnic values e.g. art, music, religion and many other customs related to civilization (Mahmood, Rasheed, Obaid, \& Shakir, 2014). Though, there were many cultural traditions in Subcontinent but the most influential traditions or values which were adopted by Pakistani nation were Islamic cultural values because these were established a long time ago by Muslim rulers (Shah, 2011). Due to Islamic hegemonic background and its association with Islamic beliefs, faith in Allah, Sufism and so many other cultural traditions Pakistani adopted Islam as their national religion (Government of Pakistan Ministry of Education Islamabad, 2011). Sufiism attracted people of Pakistan significantly because sufis represented real Islamic values and they spent their life according to real sense of Islamic culture (Mahmood, 2009).

\section{METHODOLOGY}

\section{Theoretical framework}

Halliday's (1970) SFG (Systemic Functional Grammar) and Fairclough's (1898) CDA model seem to be appropriate framework for this critical study. Here, as a key source SFG by Halliday has been used with the combination of descriptive tools of CDA by Fairclough, to unveil hidden agenda behind the text of 6,7 and $8^{\text {th }}$ classes English textbooks published by PTB Lahore, Punjab, Pakistan. Halliday's three metafunctions and Fairclough's three dimensions significantly analyze all aspects of texts related to media discourse, political discourse, academic discourse and all other texts related to cultural development. It was observed that, Fairclough's CDA model was directly affected by Halliday's SFG, and was considered an authentic framework for text analysis because it observed all textual features, e.g., presupposition, transitivity, modality and all syntactical features (Wodak, 2001). As for as, the present study is concerned, as a theoretical framework, CDA was employed 
with additional support of SFG tools of modality analysis. Only Description level of Fairclough's CDA framework with addition of Halliday's SFG (modality analysis) has been employed in present study as an analytical framework.

Figure 3.1. Fairclough's 3D model

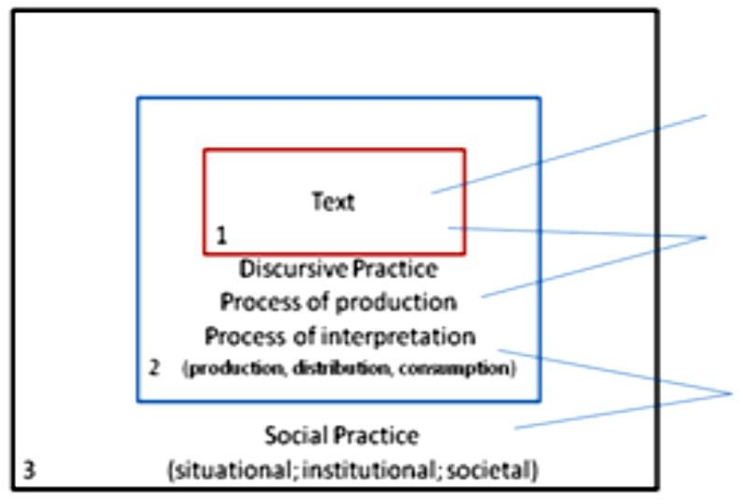

\author{
Description (text analysis) \\ Interpretation (processing \\ analysis) \\ Explanation (social change)
}

A three-dimensional model of discourse (adapted from Fairclough 1995: 98)

\title{
Modality
}

Halliday (1994) treated modality as a judgment of text producer regarding possibilities or modal verbs were related to responsibilities and obligations which writers or speakers wished to express through discourse. All lexical features related to modal verbs could be predictions, suggestions or statements, whereas, all these linguistic features could be used for referencing to indicate doubt, factuality or conviction (Verschueren, 1999). Through epistemic modality, writers construct reality related to culture, traditions or humanistic behavior while through deontic modality, writers or social entities portray obligations and necessities in the society (Fairclough, 2003). So, modal verbs could be treated as text markers which were being used to elaborate different aspects of social life and this moralization or text markers could be helpful for analytical exposure in a research study.

\section{Delimitations and Sampling}

To answer the questions of present study, significant usage of modal verbs was exposed through modality analytical approach. Elementary level, $6^{\text {th }}, 7^{\text {th }}$ and $8^{\text {th }}$ classes English language PTB 
(Punjab Textbook Board) textbooks were critically analyzed to expose representations of Islamic culture which were portrayed through significant usage of linguistic modality and these modality indicators were exposed through SFG and CDA framework accordingly. The said books were labeled as Book-1, Book.2 and Book-3 to make analytical procedure clear and precise whereas, Lesson 1 from Book-1, Lesson 1 and 3 from Book-2 and Lesson 1 and 10 had been selected for modality analysis. Sampling was purposive because it was a theoretical and qualitative type of study, so, the required purposive sampling was selected from all three PTB English language textbooks which were practiced in public as well as private institutions of the Punjab, Pakistan and as per needs of present study and modality analysis following unites were selected.

Table 1. Selected units from original text

\begin{tabular}{llll}
\hline Sr. No. & Book & Unit No. & Title \\
\hline 1 & 1 & 1 & Fair Dealing of the Holy Prophet Muhammad \\
\hline 2 & 2 & 1 & $\begin{array}{l}\text { The Last Sermon of the Rasool } \\
\text { HazaratMuhammad }\end{array}$ \\
\hline 3 & 2 & 3 & Eid-ul-Azha \\
\hline 4 & 3 & 1 & Tolerance of the Rasool \\
\hline 5 & 3 & 10 & Hazrat Umer \\
\hline
\end{tabular}

\section{ANALYSIS}

This research has been conducted to analyze an English language book series which is being practiced at a large scale in public as well as private sector institutions at elementary level in all over the province of Punjab Pakistan. These books are published by PTB (Punjab textbook Board) Lahore and practiced for the sake of teaching English language and literature to young learners of $6^{\text {th }}, 7^{\text {th }}$ and $8^{\text {th }}$ grade. This paper aims to analyze target books to point out how Islamic values, standards and norms have been portrayed implicitly or explicitly through significant usage of linguistic modality. As a continuum of research sample the selected books have been labeled as Book- $1=6^{\text {th }}$ class, Book $-2=7^{\text {th }}$ class and Book $-3=8^{\text {th }}$ Class.

\section{Portrayal of Islamic culture through modality}


As a significant tool of SFG and CDA framework, modality analysis makes possible to unveil inbred characteristics of culture which are employed through signified usage of linguistics modality. Appropriate inquiry of modality indicators leads researchers to investigate wishes, feelings, comments, suggestions and attitudes which are expressed by authors, speakers or social entities in their societal as well as institutional discourse. For this purpose, the researchers have to investigate linguistic modality indicators like 'may, can, will, could, would etc.' and these indicators are frequently used by the social members of the society and course developers as well. As for the present study is concerned, the modality analytical tools have been applied to investigate these modality indicators which construct Islamic values implicitly or explicitly.

Table 2. Epistemic modality examples from the text

\begin{tabular}{|c|c|c|c|c|}
\hline $\begin{array}{l}\text { Sr. } \\
\text { No. }\end{array}$ & $\begin{array}{l}\text { Book } \\
\text { No. }\end{array}$ & Unit No. & verbs & Selected examples from original text \\
\hline 1 & 1 & 1 & ...was & $\begin{array}{l}\text {--Muhammad (PBUH) was ---- fair and honest in - } \\
\text {-- dealing with other people even before --- } \\
\text { prophethood. } \\
\text { - It was his honesty and fair dealing in business that } \\
\text { impressed ----Khadija (RA). }\end{array}$ \\
\hline 2 & 2 & 1 & ...Is & 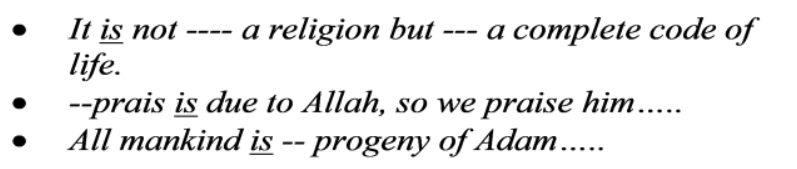 \\
\hline 3 & 2 & 3 & ..Is & $\begin{array}{l}\text { - A festival --- cultural event is -- celebration of --- } \\
\text { occasion to create -- sense of } \\
\text { brotherhood................ }\end{array}$ \\
\hline 4 & 2 & 3 & ...Are & $\begin{array}{l}\text { - Muslims ---have two festivals which are celebrated } \\
\text { with great religious devotion. }\end{array}$ \\
\hline 5 & 2 & 3 & ...Is & $\begin{array}{l}\text { - } \quad \text { Eid-ul-Azha is celebrated on } 10^{\text {th }} \text { Zil-Hajjah- } \\
\text { - } \quad \text { Eid-ul-Azah } \underline{\text { is }}^{---r e l i g i o u s ~ f e s t i v a l . ~}\end{array}$ \\
\hline 6 & 3 & 1 & ...are & $\begin{array}{l}\text { - When you are in--- position to take revenge, but } \\
\text { you do not do---- you are displaying tolerance. }\end{array}$ \\
\hline 7 & 3 & 1 & ...Was & - Abu Sufyan was -- worst enemy of Islam......... \\
\hline 8 & 3 & 1 & ...Is & - ---Rasool (PBUH) is a model--- of tolerance. \\
\hline 9 & 3 & 10 & ...was & $\begin{array}{l}\text { - Hazrat Umar was ---second Caliph of Islam. } \\
\text { - He was born at Makkah........ } \\
\text { - He was also a very good wrestler, horse-rider and } \\
\text { swordsman. } \\
\text { - He was very strict in the case of judgment. }\end{array}$ \\
\hline
\end{tabular}

Generally, some personal experiences, opinions, declarations and views are expressed through epistemic modal verbs. See example ' 1 ' in which a significant cultural and social behavior of beloved Prophet (PBUH) has been appropriately portrayed through epistemic modal verb 'was' whereas on the other hand this epistemic modality has been also used in a linguistic sequence to 
highlight fair dealings through expression of Prophet's life (see Table-2). Further in example '2' verb 'is' has been used deliberately to portray Islamic code of life, its teachings, obligations, norms and standards whereas on the other hand through significant use of 'is' some ideal characteristics of Prophet's life have been portrayed. So, both epistemic modal verbs have been employed to characterize overall ideology of Islamic social life.

Festivals, ceremonies and commemorations are treated as a part and parcel of any cultural setting; in this way author introduces two well-known social events related to Islamic cultural traditions through epistemic modality in examples 3, 4 and 5. Through portrayal of these Islamic events, i.e., Eid ul Azha and Eid ul Fitr' author exposes ideology of unity and brotherhood and on the other hand through these statements young learners are being motivated to accept exceptional values of Islam.

Prophet' realistic, exceptional and motivational social behavior related to tolerance has been exposed and highlighted through significant and appropriate usage of epistemic modal verb 'was' mentioned in example ' 6 ' in Table-2. Outstanding impact of tolerance, patience and forgiveness has been elaborated significantly to portray ideology related to pure Islamic code of life. As for example ' 7 ' is concerned, writer exemplifies Prophet's attitude related to forgiveness and tolerance to accomplish Islamic ideology of patience whereas, same practice related to construction of cultural peace and tolerance has been adopted by the author in statements mentioned in example ' 8 ' in Table 2.

Portrayal of Hazrat Umar has been presented significantly through epistemic linguistic modality mentioned in example ' 9 ' and it seems that the writer wishes to portray an ideal picture of society. Modal verb 'was' with appropriate combination of some modal adverbs 'very', 'good' and 'few', writer highlights some incomparable characteristics of Hazrat Umar (RA) to convey the message of an ideal Islamic state. On the whole as course books at elementary level PTB textbooks significantly portray real expressions of Islamic ideology through linguistic modality and convey positive messages to young learners through realistic and model behaviors of Islamic pioneers. Patriotic and Islamic ideologies are being portrayed more appropriately and precisely in PTB English language textbooks than all other English language textbook series practiced in province of Punjab (Yaqoob \& Zubair, 2012).

Table 3. Auxiliaries/modal verbs examples from the text 


\begin{tabular}{|c|c|c|c|c|}
\hline $\begin{array}{l}\text { Sr. } \\
\text { No. }\end{array}$ & $\begin{array}{l}\text { Book } \\
\text { No. }\end{array}$ & Unit No. & Verbs & Selected examples from original text \\
\hline 1 & 1 & 1 & ...Had & $\begin{array}{l}\text { - All-- people --- had --- dealing with him ------ had } \\
\text {-- praised his honesty and fair dealing. }\end{array}$ \\
\hline 2 & 2 & 1 & ...Might & $\begin{array}{l}\text { - He addressed ---- and advised them to devote their } \\
\text { lives for --- service of Islam, so that---- might gain- } \\
\text {-- glory of Allah. }\end{array}$ \\
\hline 3 & 2 & 1 & ...Has & $\begin{array}{l}\text { - - Arab has no superiority over--- non-Arab.....a } \\
\text { white has no superiority--- over black.... }\end{array}$ \\
\hline 4 & 2 & 1 & ...Shall & $\begin{array}{l}\text { - Nothing shall be legitimate ---- Muslim which } \\
\text { belongs to---fellow Muslim unless --- was given } \\
\text { freely and willingly..... }\end{array}$ \\
\hline 5 & 2 & 1 & ...Will & $\begin{array}{l}\text { - --- you will soon meet your Lord ---- you will be } \\
\text { held answerable---- for your actions. }\end{array}$ \\
\hline 6 & 2 & 1 & $\begin{array}{l}\text {...Must, } \\
\text {...should }\end{array}$ & 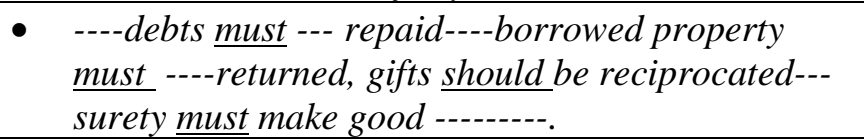 \\
\hline 7 & 2 & 1 & ...Will & $\begin{array}{l}\text { - offer prayers ------ observe fast ------ Ramadan; } \\
\text { pay ---- Zakat ----- pilgrimage to--- House of Allah } \\
\text {---obey ----rulers and you will be admitted to --- } \\
\text { Paradise--------- }\end{array}$ \\
\hline 8 & 2 & 1 & ...Can & $\begin{array}{l}\text { - -- can ---- be claimed --- ----- 'Universal Charter } \\
\text { of Human Rights'. }\end{array}$ \\
\hline 9 & 2 & 3 & ...Have & $\begin{array}{l}\text { - Muslims --- have two festivals which are } \\
\text { celebrated--- with---- religious devotion. }\end{array}$ \\
\hline 10 & 2 & 3 & ...Should & $\begin{array}{l}\text { - "Should I give----better festivals to celebrate ----- } \\
\text { "? }\end{array}$ \\
\hline 11 & 3 & 1 & ...Should & $\begin{array}{l}\text { - We----- should follow-----noble example of --- } \\
\text { tolerance of ---- Rasool (PBUH). }\end{array}$ \\
\hline 12 & 3 & 1 & ...Can & $\begin{array}{l}\text { - --- menace can only --- cured ---following --- noble } \\
\text { examples set by----- Rasool (PBUH). }\end{array}$ \\
\hline 13 & 3 & 10 & ...Could & $\begin{array}{l}\text { - He was one of ----- few persons in Makkah who } \\
\text { could read and write. }\end{array}$ \\
\hline 14 & 3 & 10 & ...Would & $\begin{array}{l}\text { - He would not spare any one, not even his -- } \\
\text { son........ } \\
\text { - "Treat your servant as would ----- yourself." }\end{array}$ \\
\hline
\end{tabular}

Modality indicators help speakers to express their viewpoints related to wishes, suggestions, feelings, ideologies etc. so, generally writers or speakers use modal verbs like may, might, can, could, would, should etc., to make their discourse dominant (Verschueren, 1999). Example '1' mentioned in Table 3 shows that a prominent and ideal social behavior of the Prophet (PBUH) has been portrayed through significant use of modal verb 'has' which magnetize people close to him and accept the teachings of Islam. Through a comparative statement and significant use of modal verb 
'might' mentioned in example ' 2 ', the writer suggests Muslims to adopt an Islamic social procedure by which they can expect to have blessings of Allah.

Auxiliary verb 'has', mentioned in example ' 3 ' has been used to introduce a golden rule of human equality and this statement condemns the negative ideology of racism because according to Islam no nation is superior to any other nation and there is no difference between black and white. Another Islamic social rule related to brotherhood and self-respect has been portrayed through modal verb 'shall', mentioned in example ' 4 '. Through modal verb 'will' in next example, the writer warns Muslims that their actions will be answerable to Allah, whereas the ideology of judgment has been highlighted as well (see Table 3).

Exchanging of physical social objects is practiced through specified rules in Islamic society, so, Islamic obligations related to exchanging money, property and gifts have been portrayed through significant usage of modal verbs 'must' and 'should' mentioned in example ' 6 ', whereas the implicit ideology behind the text could be to cultivate pure Islamic behavior among young learners. With the help of conditional statement through modal verb 'will', the writer suggests that if you follow prescribed physical and social activities you may get reward in the shape of paradise; so, the embedded relations between obligations and reward motivate students positively (see Table 3 ). Example ' 8 ' seems to be a concluding statement in which through modal verb 'can' the writer supposes authenticity of The last Sermon of Prophet (PBUH) and discursively motivates learners to adopt these golden rules related to Islamic code of life.

Commemorations, festivals, and other social ceremonies attract people because they allow people to share their pleasures and sorrows. So, in this way author represents two well-known social festivals related to Islamic traditions through Modal verbs 'Have' and 'should' mentioned in examples '9' and '10'. Through appropriate portrayal of these Islamic events, i.e., ' Eid ul Azha and Eid ul Fitr' author exposes ideology of unity and brotherhood as well.

See examples '11' and'12', through significant applications of modal verbs 'should' and 'can' the writer demonstrates learners to follow specific teachings of Islam; this way implicitly advocating his commitment towards Islamic ideology. Through wonderful picture of specialties related to Hazrat Umar's personality, Islamic unique behavioral ideologies have been advocated through modal verbs 'could' and 'would' mentioned in examples '13' and '14' (see Table 3). The analysis of above said 
linguistics modality concluded that ideology of Islamic culture has been significantly and precisely embedded in the text of elementary level PTB English language textbooks which are an authentic source of behavioral cultivations of young learners.

\section{FINDINGS AND DISCUSSION}

The present study aims to investigate cultural representations regarding hegemonic values of Islam from English Language textbooks at elementary level produced by PTB Lahore Pakistan. Furthermore, through this qualitative study, it has also been explored that how social realities are being constructed through significant use of linguistic modality in academic discourse. Modality analysis made it possible to expose authors' linguistic implications which they have used to construct positive behavior of young learners as active participants of Islamic socio-cultural practices. This study has also exposed the role of academic discourse for character building of young learners about national ideologies of the country. It is found that the ideology related to Islamic values has been willfully communicated by the writers as well as publishers (see analysis of Table 2 and 3). Likewise, through ideal behavior of the Prophet (PBUH), some extraordinary socio-cultural practices of Islam have been introduced as motivational indictors for young learners (see Table 2). Through the analysis of the Lesson-1, Book-1 it was observed that author employed social behavior of the Prophet (PBUH) to maintain character building of young learners related to Islamic social ideology. Routine life, business dealings, truthfulness and honesty of the Prophet (PBUH) were shown through academic text as social indicators which impressed the followers of Islam. As for the next selected lesson was concerned, it was critically observed that representations of Islamic code of life have been portrayed through last sermon of the prophet $(\mathrm{PBUH})$ (see Table $2 \& 3$ ).

No doubt, Commemorations, festivals, and other social ceremonies attract people because they allow people to share their feelings of pleasures and sorrows. So, the author represented two well-known social festivals ' Eid ul Azha and Eid ul Fitr' related to Islamic traditions which attracted young learners and fulfilled their aesthetic sense as well. Text of Lesson 1 and 3 of Book-3 demonstrates that the writers have applied some real life examples of Prophet's personality, e.g., tolerance, patience and forgiveness, whereas, some symbolic specialties of Hazrat Umar (RA) were also applied to elaborate essence of Islamic social ideology. So, in this way, the above said text 
applications were employed by the writers to cultivate young learners' mindset towards Islamic ideology.

The linguistic modality analysis has found that through significant use of modal verbs, some cultural, traditional, economical and behavioral characteristics of Islamic ideology were deliberately portrayed. It was also found that throughout the whole text, the Islamic cultural and behavioral ideologies were strengthened through significant use of linguistic modality, whereas, authors expressed their recommendations, suggestions and wishes through epistemic and modal verbs as well (see Table $2 \& 3$ ). During the navigation of selected units of elementary level English language textbooks, it was observed that through epistemic modality, the writers embedded specific ideas to enrich leaners' knowledge about cultural teachings of Islam whereas, through significant usage of modal verbs symbolic and balanced lifestyle of pioneers of Islam was portrayed which implicitly maintained positive behavior towards Islamic concept of social life.

\section{Conclusion}

Hegemonic, ideological and instructional practices regarding construction of social behavior are considered as essential part of political, social, media or academic discourse but as for academic or institutional discourse is concerned, it is treated as more authentic type of discourse for mind cultivation of generations. This study also confirms the previous studies that writers, researchers, authors, editors and reporters maintain cultural beliefs, trends, traditions and all other ideologies through significant use of linguistic features (Peled-Elhanan, 2012). The results of this papers reveal that locally framed English language textbooks for elementary level have included manifestations of Islamic ideologies through well-structured academic text. The CDA framework by Fairclough with additional combination of SFG viewpoint by Halliday was employed to unveil discourse glimpses related to Islamic ideology. It was found that through well framed linguistic modality, though epistemic or deontic, social and behavioral performances of the Prophet (PBUH) was portrayed while some associated symbolic events and ingredients of Islamic society were also embedded in the text. Through some binary objects related to this world and the world hereafter it was supposed to cultivate readers' lives according to golden rules of Islamic culture. It could be beneficial to mention that real life examples of the Prophet (PBUH) and Hazrat Umar (RA), ideological statements, power structure of text and binary statements through significant use of 
linguistic modality made possible for researcher to expose real impact to selected academic discourse. So, through critical analysis, results and discussion of this paper, it could be concluded that elementary level English textbooks published by PTB have sufficient discursive material for maintenance of Islamic ideology. English language textbooks published by PTB could be a resource of cultural cultivations in positive way, whereas, some textual implications of these textbooks represented foreign culture as well.

\section{References}

Alrefaee, Y., Abdul-Ghafour, A., Alazzany, M. \&Alrefaee, S. (2019). A critical discourse analysis of the selected opposition and state printed media on the representation of southern mobility in Yemen. International Journal of Linguistics, Literature and Translation (IJLLT),2(2), 136-144.

Asghar. J \& Sulaimani, A (2017). Exploring cultural representation in ESL textbooks in Pakistan: A critical linguistic overview. Academic Research International, $\quad 8(4), 264-278$.

Asghar, J. (2013). Change for the better: An evaluative study of a textbook. Language. Individual and Society, 7(1), 404-422.

Bahrami, N. (2015). Evaluating the representation of cultural elements in an in-use EFL textbook. Advances in Language and Literary Studies, 6(3), 128-137.

Byram, M., Esarte-Sarries, V., Taylor, E., \& Allat (1991). Young people's perceptions of the other culture. In D. Buttjes \& M. Byram (eds.), Mediating languages and cultures. Clevedon: Multilingual Matters.

Chen, X. \& French, D. (2008). Children's social competence in cultural context. Annual Review of Psychology, 59, 591-616.

Fairclough, N. (1989). Language and power. New York: Longman, Inc.

Fairclough, N. (1995). Critical discourse analysis: The critical study of language. London: Longman.

Fairclough, N. (2003). Analysing discourse. London: Routledge.

Government of Pakistan Ministry of Education Islamabad, (2011). National curriculum for Pakistan culture grade XI-XII. Islamabad. Pakistan. Author.

Halliday, M.A.K. (1970). Language structure and language function. In J. Lyons (Ed.), New horizons in Linguistics (pp. 140-165). Harmondsworth: Penguin. 
Halliday, M. (1994) An Introduction to functional grammar (2 ${ }^{\text {nd }}$ ed). London: Edward Arnold.

Jat, A.R.L., Pathan, H. \& Shah, S.W.A. (2018). Representation of national heroes in English language textbooks taught at government higher secondary schools of Sindh, Pakistan. Education and Linguistics Research, 4(2), 25-42.

Mahmood, M. A. (2009). A corpus-based analysis of Pakistani English. Doctoral Thesis,Bahauddin Zakariya University Multan, Pakistan.

Mahmood, M. A., Asghar, Z. M., \& Hussain, Z. (2012). Cultural representation in ESL textbooks in Pakistan: A case study of "Step Ahead 1". Journal of Education and Practice, 3(9), $35-42$.

Mahmood, M. A., Rasheed, S. Obaid, M. \& Shakir, A (2014). Representation of class system through English textbooks in Pakistan. Research on Humanities and Social Sciences, 4(9), 2224-5766.

Mansoor, S. 2004. The medium of instruction dilemma: Implications for language planning in higher education. In S. Mansoor, S. Meraj, \& A. Tahir (Eds.), Language policy, planning, \& practice: A South Asian perspective. Karachi: Agha Khan University.

McKay, S.L. (2003). Towards an appropriate EIL pedagogy: Re-examining common ELT assumptions. International Journal of Applied Linguistics, 13(1), 1-22.

McConachy, T., \& Hata, K. (2013). Addressing textbook representations of pragmatics and culture. ELT Journal, 67(3), 294-301.

Morris, M.W. (2014). Values as the essence of culture: Foundation or fallacy? Journal of Cross-Cultural Psychology, 45(1), 14-24.

Peled-Elhanan, N. (2012). Palestine in Israeli schoolbooks: Ideology and propaganda in education. London: I.B. Tauris \& Co Ltd.

Pennycook, A. (2010). Language as local practice. New York: Routledge.

Punjab Curriculum \& Textbook Board, Lahore, (2017). English 6. Lahore. Pakistan: Punjab Textbook Board.

Punjab Curriculum \& Textbook Board, Lahore, (2017). English 7. Lahore. Pakistan: Punjab Textbook Board.

Punjab Curriculum \& Textbook Board, Lahore, (2017). English 8. Lahore. Pakistan: Punjab Textbook Board. 
Qadeer, A., Tahir, A., Chishti, M.I., \& Ali, Z. (2020). Discursive practices of Pakistani press through headlines in shaping up political realities. Erevna: Journal of Linguistics and Literature, 4(2), 53-72.

Samovar, L., \& Porter, R. E. (2004). Communication between cultures. London: Wadsworth/Thomson Learning.

Schwartz, S. H. (2006). A theory of cultural value orientations: Explication and applications. Comparative Sociology, 5, 136-182.

Shah, S.A.M., Amjad, S. (2011). Cultural diversity in Pakistan: National vs provincial. Mediterranean Journal of Social Sciences, 2(2), 1-14.

Tahir, D. M., \& Iqbal, M. B. (2012). Representation of cultures in English textbook discourses in Pakistan: A critique. International Journal of Research in Linguistics and Lexicography, 1 (3) 51-58.

Trommsdorff, G. (2000) Subjective experience of social change in individual development. In J. Bynner \& R. K. Silbereisen (Eds.), Adversity and challenge in life in the new Germany and in England (pp. 87-122). Basingstoke, England: Macmillan.

van Dijk, T. A. (1993). Principles of critical discourse analysis. Discourse and Society, 4, 249-284.

Wodak, R. (2001). The discourse-historical approach. In R. Wodak, \& M. Meyer (Eds.), Methods of critical discourse analysis (pp. 63-94). London: Sage.

Yaqoob, M. T., Zubair, S. (2012). Culture, class and power: A critique of Pakistan English language textbooks. Pakistan Journal of Social Sciences, 32(2), 133-147. 